\title{
COMBINED APPLICATION OF ORIGANUM VULGARE L. ESSENTIAL OIL AND ACETIC ACID FOR CONTROLLING THE GROWTH OF STAPHYLOCOCCUS AUREUS IN FOODS
}

\author{
Evandro Leite de Souza*; Jefferson Carneiro de Barros; Maria Lúcia da Conceição; Nelson Justino Gomes Neto; \\ Ana Caroliny Vieira da Costa
}

Laboratório de Microbiologia de Alimentos, Departamento de Nutrição, Centro de Ciências da Saúde, Universidade Federal da Paraíba, João Pessoa, Paraíba, Brasil

Submitted: May 27, 2008; Returned to authors for corrections: August 16, 2008; Approved: March 31, 2009.

\begin{abstract}
This study evaluated the occurrence of an enhancing inhibitory effect of the combined application of Origanum vulgare L. essential oil and acetic acid against Staphylococcus aureus by the determination of Fractional Inhibitory Concentration (FIC) index and kill-time assay in nutrient broth, meat broth and in a food model (meat pieces). Acetic acid showed MIC and MFC of 0.6 and $1.25 \mu \mathrm{L} . \mathrm{mL}^{-1}$, respectively. For $O$. vulgare essential oil MIC and MBC were 1.25 and $2.5 \mu \mathrm{L} . \mathrm{mL}^{-1}$, respectively. FIC indexes of the mixture of essential oil and acetic acid at MIC x $1 / 2$ were $\leq 1.0$, showing an additive effect. No synergy was found at kill-time study. Antistaphylococcal effect of the antimicrobials alone or in mixture (MIC x $1 / 2$ ) was lower in meat than in nutrient and meat broths. The effective combination of essential oils and organic acids could appear as an attractive alternative for the food industry, as the doses to inhibit the microbial growth in foods can be lowered.
\end{abstract}

Key words: essential oil, organic acid, combined use, anti-staphylococcal effect.

\section{INTRODUCTION}

Staphylococcal food poisoning is a common disease transmissible by improper handling and storage of food contaminated with staphylococci (42). In many countries, Staphylococcus aureus is considered the second or third most common pathogen responsible for outbreaks of food poisoning (33).

Staphylococcus enterotoxins (SEs) are a family of serologically well defined, low-molecular-weight proteins (26$30 \mathrm{kDa}$ ) produced by some strains of Staphylococcus aureus $(23,31)$. Twenty different types of SEs, i.e., SEA-SEE, SEG-SER, and SEU have already been discovered, however SEA-SEE are the most common enterotoxins involved in staphylococcal food poisoning (20). These toxins are heat stable, resistant to gut proteases, and stable over a wide range of $\mathrm{pH}(\mathrm{pH} 4-10)$ (37). Foods that are frequently associated with staphylococcal food poisoning include meat, salads, cream-filled bakery items, sandwich accoutrements, and dairy products $(7,18)$.
The constant threat posed by $S$. aureus for food industry stimulates the search for successful procedures to be applied in food conservation in order to control its survival and production of toxic metabolites (3). Essential oils has been known as one of the more interesting compounds to be applied as alternative antimicrobial agents in foods, including for anti$S$. aureus purposes $(2,35)$.

The increased demand of consumers for additive-free, fresher, more natural tasting foods and with a smaller impact on the environment, while maintaining the microbiological safety, provokes many researchers to investigate the antimicrobial effects of natural compounds (12). Several investigations have confirmed the antimicrobial action of essential oils against foodborne pathogens and spoilage bacteria in synthetic media, food systems and real foods (39). However, higher concentrations of essential oils are needed to achieve the same effect in foods as in synthetic media. These higher concentrations needed to inhibit spoilage and pathogen bacteria in food matrixes could often exceed the flavor threshold acceptable to consumers (27).

*Corresponding Author. Mailing address: Laboratório de Microbiologia de Alimentos, Departamento de Nutrição, Centro de Ciências da Saúde, Universidade Federal da Paraíba, João Pessoa, Paraíba, Brasil. Tel.: 8332167499 Fax: 8332167499 . E-mail: evandroleitesouza@ccs.ufpb.br 
If essential oils are expected to be widely applied as antimicrobials in foods, the organoleptic impact must be considered (30). Combination of essential oils with existing physical or chemical treatments (Hurdle Technology concept) could rise as an effective approach for reinforcing their natural antimicrobial effects. The addition of small amounts of other natural preservatives may be a way to provide the balance between sensory acceptability and antimicrobial efficacy $(17,29)$.

Weak organic acids are either naturally present as constituents of the food, produced in different fermented foods by desirable food-grade starter cultures, or added to the products through the food formulation. Acetic acid, also known as ethanoic acid, is one of the simplest carboxylic acids. Acetic acid is usually used as vinegar (4\%) or as salts of sodium and calcium at $25 \%$ higher levels in pickles, salad, dressings, and sauces. It is cited to be more effective against bacteria than yeasts and moulds. Besides its use in foods, acetic acid has been recommended for use (1 to $2 \%$ level) in carcass wash to reduce bacterial levels. In the food industry acetic acid is used under the food additive code E260 as an acidity regulator (10).

Recently, some studies have focused on the biological properties of the essential oil from Origanum vulgare L., Lamiaceae, and their major constituents $(38,39)$. O. vulgare, commonly known as oregano, possesses many therapeutic properties (e.g. diaphoretic, anti-inflammatory, antiseptic, carminative, antispasmodic and tonic) being used in medicine native systems for a long. $O$. vulgare essential oil has presented interesting results in inhibiting the growth of bacteria, fungi and synthesis of microbial metabolites $(4,31)$.

This study aimed to investigate the occurrence of an enhancing anti-S. aureus effect between $O$. vulgare essential oil and acetic acid in different media on the base of FIC index and kill-time assay. To date, no reference data have been found about the effect of the combined application of $O$. vulgare essential oil and acetic acid at sub-inhibitory concentrations against the foodborne pathogen $S$. aureus.

\section{MATERIALAND METHODS}

\section{Antimicrobial agents}

Acetic acid P.A. (85 - 90\%) was obtained from Vetec Química Fina Ltda. (Rio de Janeiro, Brazil). Stock solutions of the acid were made in distilled water. The essential oil from $O$. vulgare $\mathrm{L}$. was supplied by Ferquima Ind. e Com. Ltda. (Vargem Grande Paulista, São Paulo, Brazil). Stock solution of the essential oil was prepared in nutrient broth using bacteriological agar $(0.15 \%$ $w / v)$ as stabilizing agent (6).

\section{Bacterial strains}

S. aureus QCA, S. aureus QCB, S. aureus QCC, S. aureus QCD, S. aureus QCF, S. aureus QCG, S. aureus QCH and $S$. aureus QCI obtained from the Microorganism Collection, Laboratory of Food Microbiology, Health Sciences Center, Federal University of Paraíba, João Pessoa, Brazil were used as test microorganisms. The strains were isolated from unripened cheese samples by the standard procedures (41) and identified by positive Gram test, positive catalase activity, positive coagulase production (level four), positive thermonuclease production, acid production from mannitol anaerobically, acid production from glucose anaerobically and lysostaphin positive sensitivity $(1,5)$.

Inocula used in the antimicrobial assays were obtained from overnight cultures grown on nutrient agar slants at $37^{\circ} \mathrm{C}$ and diluted in sterile saline solution $(0.85 \% \mathrm{w} / \mathrm{v})$ to have a final concentration of approximately $10^{7}$ colony forming unity per $\mathrm{mL}$ (cfu. $\mathrm{mL}^{-1}$ ) (adjusted according to the turbidity of 0.5 McFarland scale tube).

\section{Preparation of meat broth}

Bovine meat steaks were trimmed for all external fat and cut in pieces of uniform sizes $(3 \times 3 \times 3 \mathrm{~cm})$. The meat pieces were cooked during $20 \mathrm{~min}$ at $80^{\circ} \mathrm{C}$. About $500 \mathrm{~mL}$ of meat broth were obtained and vacuum filtered using Whartman $\mathrm{n}^{\circ} 1$. The filtrate was sterilized by using autoclave for $15 \mathrm{~min}$ (121 atm). After that, the broth was stored at $-50^{\circ} \mathrm{C}$ in aliquots of $50 \mathrm{~mL}$. When required one aliquot was thawed under refrigeration $\left(7^{\circ} \mathrm{C}\right.$, $\pm 1^{\circ} \mathrm{C}$ ) and used for the experimental analysis.

\section{Determination of the Minimum Inhibitory Concentration (MIC) and Minimum Bactericidal Concentration (MBC)}

MIC and MBC values of acetic acid were determined using the macrodilution in broth procedure. $5 \mathrm{~mL}$ of double strength nutrient broth was inoculated with $1 \mathrm{~mL}$ of the bacterial inocula ( ca $10^{7}$ cfu. $\mathrm{mL}^{-1}$ ). After that, $4 \mathrm{~mL}$ of the acetic acid solution with proper concentration was added and followed by shaking for $30 \mathrm{~s}$. The system was incubated for 24 hours at $37^{\circ} \mathrm{C}$ without shaking. MIC was defined as the lowest concentration of the acid required to completely prevent visible bacterial growth. An aliquot $(100 \mu \mathrm{L})$ of the tubes with no visible bacterial growth was subcultured on sterile Nutrient agar Petri dishes at $37^{\circ} \mathrm{C}$ for $48 \mathrm{~h}$ to determine if the inhibition was reversible or permanent. MBC was defined as the lowest concentration which no growth was noted on Nutrient agar. Control flasks without acetic acid were tested in the same way (15).

\section{Synergy assays in broth}

The study of synergy of $O$. vulgare essential oil and acetic acid was carried out by determining Fractional Inhibitory Concentration (FIC). For this, was used the macrodilution in broth procedure as previously described. FIC was calculated as follow: FIC: MIC of the oil in combination of acetic acid/MIC of the oil alone. Synergy was FIC $\leq 0.5$; addition was FIC $>0.5$ to 4 ; and antagonism was FIC > $4(17,26)$. 
For analyzing 96-h kill times curves synergy was defined as $\geq 2 \log$ cycles increase-bacterial killing as compared to the most active antimicrobial agent in combination (16). For this, 5 $\mathrm{mL}$ of double strength nutrient broth or meat broth was inoculated with $1 \mathrm{~mL}$ of the bacterial suspension ( $\mathrm{ca} 10^{7}$ cfu. $\mathrm{mL}^{-1}$ ). After that, $4 \mathrm{~mL}$ of the assayed antimicrobial agent (oil: MIC, acid: MIC, oil: $1 / 2$ MIC + acid: $1 / 2$ MIC) solution proper concentration was added to the system and gently shaken for $30 \mathrm{~s}$. The system was incubated at $37^{\circ} \mathrm{C}$. At different time intervals $(0,24,48,72$ and $96 \mathrm{~h}), 1 \mathrm{~mL}$ of the suspension was serially diluted $\left(10^{-1}-10^{-5}\right)$ in sterile peptone water $(0.1 \% \mathrm{w} / \mathrm{v})$ and inoculated on nutrient agar Petri dishes for $24 \mathrm{~h}$ at $37^{\circ} \mathrm{C}$. Control flasks without essential oil or acetic acid were tested in the same way. The mean number of colonies was counted and compared with that found in the control assay. The results were expressed in log of cfu.mL $\mathrm{mL}^{-1}$.

\section{Synergy assays in food model}

Bovine meat steaks were trimmed for all external fat and cut in pieces of uniform sizes $(3 \times 3 \times 3 \mathrm{~cm})$. The meat pieces were put in scraped glass flasks and sterilized using autoclave $\left(121^{\circ} \mathrm{C}\right.$ for $15 \mathrm{~min}, 121 \mathrm{~atm})$. After that, meat pieces were inoculated with a staphylococcal suspension according the following procedure: the pieces were individually submerged in $50 \mathrm{~mL}$ of the bacterial inoculum $\left(\mathrm{ca} 10^{7} \mathrm{cfu} . \mathrm{mL}^{-1}\right.$ prepared in sterile $0.85 \%$ saline solution, $S$. aureus QCE), rotated with sterile glass stick for $1 \mathrm{~min}$ to ensure even inoculation, air dried for $30 \mathrm{~min}$ in a biosafety cabinet before washing with the antimicrobials. The pieces were randomly divided into four groups and immersed for $30 \mathrm{~s}(1: 4 \mathrm{w} / \mathrm{v})$ as follow: (1) control - dipped in sterile distilled water; (2) dipped in the essential MIC solutions; (3) dipped in acetic acid MIC solutions; and (4) dipped in oil ( $1 \frac{1}{2}$ MIC) + acetic acid ( $1 / 2$ MIC) solution. The pieces were put in sterile sealed sterile polypropylene cups and stored under refrigeration $\left(7^{\circ} \mathrm{C}, \pm 1^{\circ} \mathrm{C}\right)$. At $0,24,48,72$ and $96 \mathrm{~h}$ of storage the meat samples were submitted to count of $S$. aureus according to procedure described by Vanderzant and Spplittstoesser (41). The results were described in log of cfu per gram of meat (log cfu/g meat).

All antimicrobial assays were carried out in triplicate and the results are expressed as average of the three parallel assays.

\section{Statistical analysis}

Statistical analysis was performed to determine significant differences $(p<0.01)$ by ANOVA followed for Tukey test in the bacteria kill time assays. For this was used Sigma stat 2.03 computer program.

\section{RESULTS AND DISCUSSION}

In our previous experiments $O$. vulgare essential oil showed MIC value of $0.6 \mu \mathrm{L} \cdot \mathrm{mL}^{-1}$, while $\mathrm{MBC}$ was in a range of $1.25-2.5$ $\mu \mathrm{L} . \mathrm{mL}^{-1}$ (not published data) toward the tested $S$. aureus strains. Values of MIC and MBC of acetic acid on each $S$. aureus strain by macrodilution assay are given in Table 1. All nine test strains were sensitive to acetic acid being found MIC and $\mathrm{MBC}$ values of 0.6 and $1.25 \mu \mathrm{L} \cdot \mathrm{mL}^{-1}$, respectively (data not showed). MIC of the essential oil and acetic acid were the same for the all strains. MBC of acetic acid was two-folds higher than the corresponding MIC.

FIC indices of the combined application of $O$. vulgare essential oil and acetic acid on $S$. aureus strains are given in Table 2. FIC indices were 1.0 for the strains showing an additive interaction of the antimicrobials. Test strains presented capability to grow at sub-inhibitory concentrations ( $1 / 2 \mathrm{MIC}, 1 / 4$ MIC) of both antimicrobials when applied alone (data not showed). Interactions between antimicrobials are still a contentious issue. At theory, synergy is found when the effect of the combined compounds is greater than the sum of the

Table 1. MIC and MBC of acetic acid against $S$. aureus strains.

\begin{tabular}{cccc}
\hline \multirow{2}{*}{ Strains } & \multicolumn{2}{c}{ Acetic acid $\left(\mu \mathrm{L} . \mathrm{mL}^{-1}\right)$} & \multirow{2}{*}{ Strain viability } \\
\cline { 2 - 3 } & MIC & MBC & \\
\hline QCA & 0.6 & 1.25 & + \\
QCB & 0.6 & 1.25 & + \\
QCC & 0.6 & 1.25 & + \\
QCD & 0.6 & 1.25 & + \\
QCE & 0.6 & 1.25 & + \\
QCF & 0.6 & 1.25 & + \\
QCG & 0.6 & 1.25 & + \\
QCH & 0.6 & 1.25 & + \\
QCI & 0.6 & 1.25 & + \\
\hline
\end{tabular}

${ }^{a}$ : capability of the strain to grow in nutrient broth without adding essential oil.

Table 2. FIC indexes of the combined action of $O$. vulgare L. essential oil and acetic acid to $S$. aureus strains.

\begin{tabular}{cccccc}
\hline & & \multicolumn{4}{c}{ Control } \\
\cline { 3 - 6 } Strains & FIC & \multicolumn{3}{c}{$\begin{array}{c}\text { O. vulgare } \\
\text { essential oil }\end{array}$} & Acetic acid \\
\cline { 3 - 6 } & & MICx & $\mathrm{MICx}$ & $\mathrm{MICx}$ & $\mathrm{MICx}$ \\
& & $1 / 2$ & $1 / 4$ & $1 / 2$ & $1 / 4$ \\
\hline S. aureus QCD & 1.0 & + & + & + & + \\
S. aureus QCE & 1.0 & + & + & + & + \\
S. aureus QCF & 1.0 & + & + & + & + \\
\hline
\end{tabular}

+ : capability of the strain to grow in nutrient broth added of the antimicrobial agent at the assayed concentration. 
individual effects. Regarding the FIC index assay, synergy occurs at a FIC index $<1$, however as the dilution method can present $\mathrm{a} \pm 1$ error dilution convention states that synergy is $\leq$ 0.5 . However, a minor synergy (i.e. up to FIC 1 ) could be regarded to present some practical importance (16).

McKay et al. (26) reported that the advantage of using FIC index assay in combination with kill time studies is the availability of much more information about the kinetic of microbial kill resulting in a dynamic picture of the antimicrobial interaction.

Kill-time of $S$. aureus QCE when exposed to $O$. vulgare essential oil (MIC), acetic acid (MIC) and $O$. vulgare essential oil ( $1 / 2$ MIC) in combination of acetic acid ( $1 / 2$ MIC) in nutrient broth are given in Fig. 1. The oil showed a sharp drop in the bacterial count after $24 \mathrm{~h}$ and after this interval on the counts were always at $2 \log$ cycles. Acetic acid caused a clear linear decrease in bacterial inoculum along the evaluated intervals, being noted a bacterial count of $2 \log$ cycles after $96 \mathrm{~h}$. Combination of essential oil and acetic acid at sub-inhibitory concentrations provided a reduction of $3 \mathrm{log}$ cycles $(99.9 \%$ killing rate) in initial bacterial inocula in meat broth after $72 \mathrm{~h}$. No significant difference $(p>0.05)$ was found among the bacterial counts for the nutrient broth added of essential oil, acetic acid and essential oil combined of acetic acid.

Kill-time of $S$. aureus QCE when exposed to $O$. vulgare essential oil (MIC), lactic acid (MIC) and $O$. vulgare essential oil ( $1 / 2$ MIC) in combination of acetic acid ( $1 / 2$ MIC) in meat broth are shown in Fig. 2. In meat broth the oil caused a prominent drop in the bacterial inoculum after $24 \mathrm{~h}$, and kept a strong inhibitory effect on the bacterial cell viability up to $96 \mathrm{~h}$. During the evaluated intervals the bacterial counts found for the media added of essential oil and acetic acid at sub-inhibitory concentrations showed a clear time exposure linear killing-rate. In meat broth added of essential oil the counts were significantly lower $(p<0.01)$ than those found in the control assay and in the meat broth added of acetic acid. Significant difference $(p<0.01)$ was noted between the counts found for the meat broth added of essential oil and of acetic acid alone.

Kill-time of $S$. aureus QCE when exposed to $O$. vulgare essential oil (MIC), acetic acid (MIC) and $O$. vulgare essential oil ( $1 / 2$ MIC) in combination of acetic acid ( $1 / 2$ MIC) in meat are shown in Fig. 3. Anti-staphylococcal effect of all treatments, excepting the control assay, was smaller in meat in comparison to its addition in nutrient and meat broth. No significant difference $(p<0.01)$ was found for the microbial counts in meat treated with the antimicrobials alone or in mixture.

The application of antimicrobials alone or in mixtures in meat showed a similar drop in the microbial inoculum after $24 \mathrm{~h}$, and a smaller kill-effect was noted in the following intervals. These results could suggest a more difficulty of the antimicrobial to disperse into the food model (meat pieces), since it could impair the contact of antimicrobials with target microorganism.

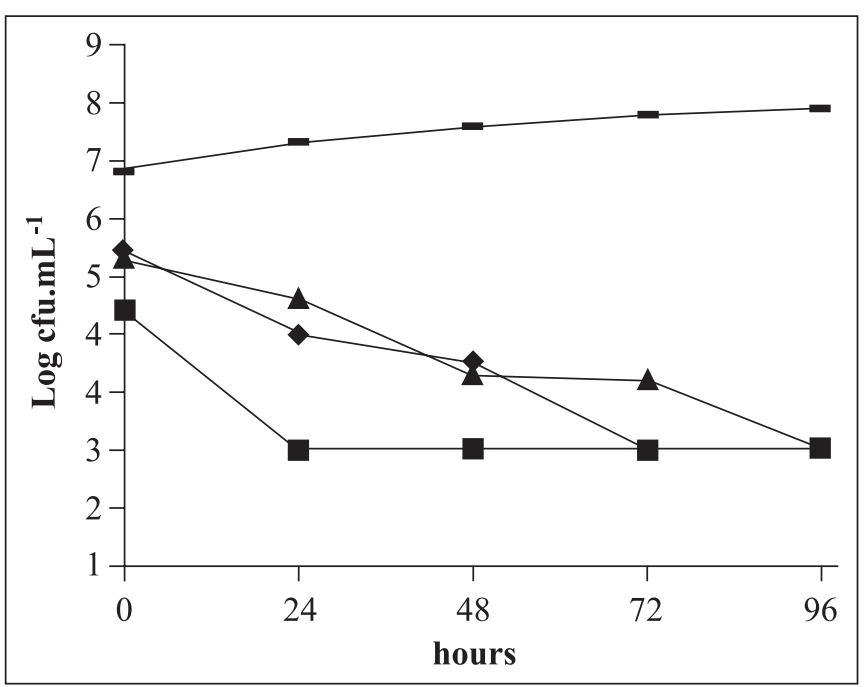

Figure 1. Survivors curves for Staphylococcus aureus QCE in nutrient broth at $37^{\circ} \mathrm{C}$ as a function of antimicrobial

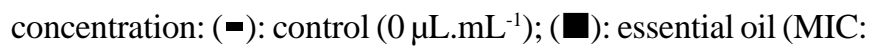
$\left.0.6 \mu \mathrm{L} \cdot \mathrm{mL}^{-1}\right) ;(\boldsymbol{\Delta})$ : acetic acid $\left(0.6 \mu \mathrm{L} \cdot \mathrm{mL}^{-1} ;(\bullet)\right.$ : essential oil (MIC x 1/2:0.3 $0 . \mathrm{L}^{-1}$ ) + acetic acid (MIC x 1/2: $0.3 \mu \mathrm{L} \cdot \mathrm{mL}^{-1}$ ). The detection limit for viable cells was $2 \log$ cfu. $\mathrm{mL}^{-1}$. Where no cells were recovered, the detection limit is indicated.

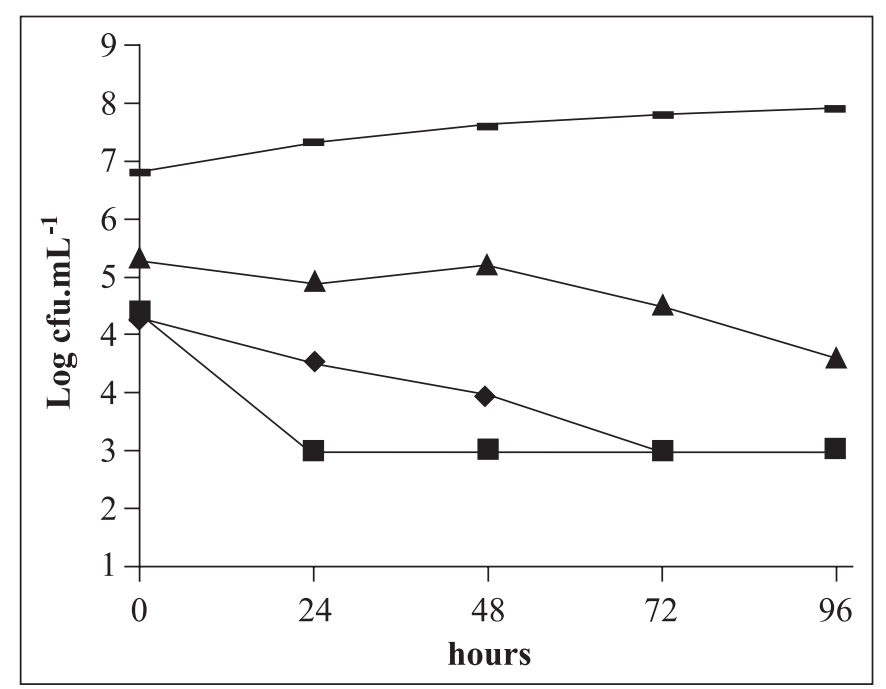

Figure 2. Survivors curves for Staphylococcus aureus QCE in meat broth at $37^{\circ} \mathrm{C}$ as a function of antimicrobial concentration:

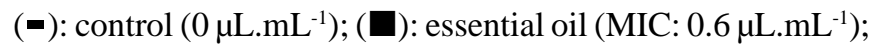
$(\boldsymbol{\Delta})$ : acetic acid (MIC: $0.6 \mu \mathrm{L} \cdot \mathrm{mL}^{-1} ;(\diamond)$ : essential oil $\left(\mathrm{MIC} \mathrm{X}^{1 / 2}\right.$ : $\left.0.3 \mu \mathrm{L} \cdot \mathrm{mL}^{-1}\right)+$ acetic acid $\left(\mathrm{MIC} \mathrm{x} 1 / 2: 0.3 \mu \mathrm{L} \cdot \mathrm{mL}^{-1}\right)$. The detection limit for viable cells was $2 \log$ cfu.mL $\mathrm{mL}^{-1}$. Where no cells were recovered, the detection limit is indicated. 


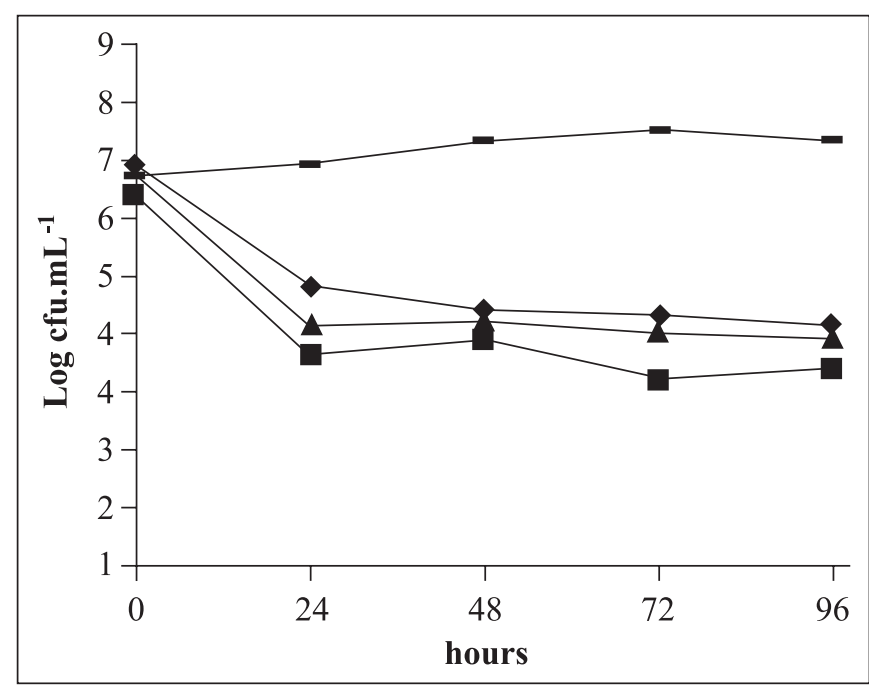

Figure 3. Survivors curves for Staphylococcus aureus QCE in meat at $7^{\circ} \mathrm{C}$ as a function of antimicrobial concentration:

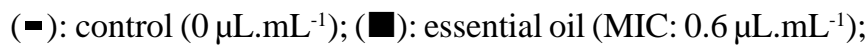

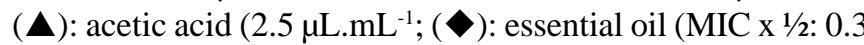
$\left.\mu \mathrm{L} . \mathrm{mL}^{-1}\right)+$ acetic acid $\left(\mathrm{MIC} \mathrm{x}^{1 / 2}: 0.3 \mu \mathrm{L} \cdot \mathrm{mL}^{-1}\right)$. The detection limit for viable cells was $2 \log$ cfu.mL ${ }^{-1}$. Where no cells were recovered, the detection limit is indicated.

Counts found in meat exposed to antimicrobials alone or in combination showed no significant difference $(p>0.01)$.

Elliopoullos and Moellering (13) stated that the occurrence of synergy between compounds on the base of kill-time study is also generally reported when the combined antimicrobials demonstrate an additional one log reduction compared to the sum of the lethal effects of each preservative. This definition of synergy is based on the hypothesis that the inhibitory effect of each compound is linear with concentration when its act alone. Although, no clear synergy was found between the tested antimicrobials in kill-time study it is interesting to cite that their combination at $1 / 2$ MIC caused a level of inhibition of the $S$. aureus cell viability as intense as that noted for the essential oil (the most active compound) at a maximum time of $72 \mathrm{~h}$ in all growth media.

It is supposed that the high levels of fat and lower content of water in foodstuffs may hamper the progress of antibacterial agents to the target site in the bacterial cell. If the essential oil dissolves in the lipid phase of the food there will be relatively less available to act on bacteria present in aqueous phase. Moreover, the physical structure of a food may limit the antibacterial activity of an essential oil (9).

It has generally been found that a greater concentration of essential oils is needed to achieve the same antibacterial effect in foods (34). The ratio has been cited to be approximately twofold in semi-skimmed milk (21), 10 -fold in pork liver sausage (32), 50-fold in soup (40) and 25- to 100-fold in soft cheese (27).

Regarding that higher concentrations of plant essential oils are generally required when added to food, the application of essential oils in food may be limited due to changes in organoleptic and textural quality (11). Although, the mixtures of antimicrobials showed no synergy in the performed assays, combining $O$. vulgare essential oil and acetic acid at subinhibitory concentrations has some potential for practical application to extend the shelf-life of foods, particularly, meat products.

Few studies have focused on the antimicrobial activity of combinations of plant products in the presence of other inhibiting compounds. Activities of $O$. vulgare essential oil constituents (thymol and carvacrol) against Bacillus cereus and Listeria monocytogenes are enhanced by nisin (14). Blaszyk and Holley (8) found that sodium citrate can increased the inhibitory action of eugenol. Lambert et al. (24) reported that carvacrol and thymol in combination were additive against $S$. aureus and $P$. aeruginosa.

Guttierrez et al. (17) found an additive effect by FIC index when oregano essential oil was applied in combination to thyme or marjoram essential oil toward P. aeruginosa, B. cereus, E. coli and L. monocytogenes. According to the authors as the assayed essential oils possess similar composition, their combination may exhibit addition rather than a synergistic effect. Antimicrobial activity depends not only on chemical composition but on lipophilic properties hence the potency of functional groups or aqueous solubility and the mixtures of compounds with different biochemical properties may increase the essential oil efficacy (17).

No much of literature about the mechanism for developing of the antibacterial activity when combination of essential oils and organic acids are applied. Studies on the antibacterial mechanism of phenolic compounds found in essential oils focused on their effects on the cellular membrane changing its structure and function, resulting in swelling increased permeability (36). The damage to cell membrane might explain the observed effects, since phenolic could cause sublethal injury to cell membranes, causing disruption of proton motive force, due loss of $\mathrm{H}^{+}$-ATPase (24). This could make bacteria more susceptible to acid environment. Moreover, at low $\mathrm{pH}$ the hidrophobicity of an essential oil increases, enabling it to more easily dissolve in the lipids of the cell membrane of target bacteria (22).

It is known that organic acids can interact with other preservatives to enhance their effects (12). Acetic and lactic acid was found to enhance the antilisterial effects of monolaurin (28). Lactic acid also increased the susceptibility of $L$. monocytogenes to heat shock in culture media (19).

The results presented in this study showed by our knowledge at first time the effect of the simultaneous combined application of $O$. vulgare essential oil and acetic acid at sub-inhibitory 
concentrations on the inhibition of S. aureus on the base of FIC index and kill-time study. The effective combination of essential oils and organic acids could provide a more natural and attractive alternative to industry, meaning an additional barrier to inhibit the growth and survival of pathogens and spoilage microorganism in foods. Moreover, our results encourage further researches focusing the application of essential oils in low doses and other preservative hurdles, since it arises as an interesting approach for the improvement of food safety when considering the current demand of consumers and sensory quality of foods.

\section{RESUMO}

\section{Aplicação combinada do óleo essencial de Origanum vulgare $\mathrm{L}$. e ácido acético para o controle do crescimento de Staphylococcus aureus em alimentos}

Este estudo avaliou a ocorrência de um efeito inibitório potencializado quando da aplicação combinada do óleo essencial de O. vulgare e ácido acético sobre Staphylococcus aureus através da determinação Concentração Inibitória Fracional (FIC) e de ensaios de tempo de morte em caldo nutriente, caldo base carne e em um modelo alimentar (pedaços de carne). $\mathrm{O}$ ácido acético mostrou um valor de CIM e CBM de 0,6 e 1,25 $\mu \mathrm{L} \cdot \mathrm{mL}^{-1}$, respectivamente. Estudos prévios encontraram valores de CIM e CBM para o óleo essencial de $O$. vulgare sobre as cepas teste de $S$. aureus de 1,25 e 1,5 $\mu \mathrm{L} . \mathrm{mL}^{-1}$, respectivamente. Valores de índices de CIF da mistura do óleo essencial e ácido acético na concentração de CIM x 1/2 foram $\leq 1,0$ caracterizando uma interação de adição. Nenhum efeito sinérgico foi encontrado nos ensaios de tempo de morte. O efeito anti-estafilocócico dos antimicrobianos isolados ou em combinação (CIM x 1/2) foi menor quando aplicado em carne em comparação a sua adição em caldo nutriente e caldo carne. A efetiva combinação de óleos essenciais e outros agentes preservativos pode ser reconhecida como uma alternativa promissora para a indústria de alimentos, podendo viabilizando a diminuição de doses de antimicrobianos aplicadas para inibir o crescimento microbiano em alimentos.

Palavras-chave: óleo essencial, ácidos orgânicos, uso combinado, efeito anti-estafilocócico.

\section{REFERENCES}

1. AOAC International. (1995). Official Methods of Analysis, 16th ed., sec. 975.55. AOAC International, Arlington, VA.

2. Bajpai, V.K.; Rahman, A.; Choi, U.K.; Youn, S.J.; Kang, S.C. (2007). Inhibitory parameters of the essential oil and various extracts of Metasequoia glyptostroboides Miki ex Hu to reduce food spoilage and food-borne pathogens. Food Chem., 105, 1061-1066.

3. Basti, A.A.; Misaghia, A.; Khaschabib, D. (2007). Growth response and modelling of the effects of Zataria multiflora Boiss. essential oil, $\mathrm{pH}$ and temperature on Salmonella Typhimurium and Staphylococcus aureus. Lebens.-Wiss. U-Technol., 40, 973-981.
4. Baydar, H.; Sagdiç, O.; Ozkan, G.; Karadogan, T. (2004). Antibacterial activity and Composition of essential oils from Origanum, Thymbra and Sartureja species with commercial importance in Turkey. Food Cont., 15, 169-172.

5. Bennett, R.W.; Yeterian, M.; Smith, W.; Coles, C.M.; Sassaman, M.; McClure, F.D. (1986). Staphylococcus aureus identification characteristics and enterotoxigenicity. J. Food Sci., 51, 1337-1339.

6. Bennis, S.; Chami, F.; Chami, N.; Bouchikhi, T.; Remma, A. (2004). Surface alteration of Saccharomyces cerevisae induced by thymol and eugenol. Let. Appl. Microbiol., 38, 454-458.

7. Blaiotta, G.; Ercolini, D.; Pennacchia, C.; Fusco, V.; Casaburi, A.; Pepe, O. (2004). PCR detection of staphylococcal enterotoxin genes in Staphylococcus spp strains isolated from meat and dairy products. Evidence for new variants of seG and seI in S. aureus AB-8802. J. Appl. Microbiol., 97, 719-30.

8. Blaszyk, M.; Holley, R.A. (1998). Interaction of monolaurin. eugenol, and sodium citrate on growth of common meat spoilage and pathogenic organisms. Int. J. Food Microbiol., 39, 175-183.

9. Burt, S. (2004). Essential oils: their antibacterial properties and potential applications in foods - a review. Int. J. Food Microbiol., 94, 223-253.

10. Costa, V.M.; Basso, T.O.; Angeloni, L.H.P.; Oetterer, M.; Basso, L.C. (2008). Produções de ácido acético, etanol e dos isômeros óticos do ácido lático por linhagens de Lactobacillus isoladas de fermentações alcoólicas industriais. Cienc. Agrotec., 32, 503-509.

11. Devlieghere, F.; Vermeiren, L.; Debevere, J. (2004). New preservation technologies: possibilities and limitations. Int. Dairy Prod., 14, 273-285.

12. Dimirtieviæ, S.I.; Mihajlovski, K.R.; Antonoviæ, D.G.; MilanoviæStevanoviæ, M.R.; Mijin, D.Z. (2007). A study of the synergistic antilisterial effects of a sub-lethal dose of lactic-acid and essential oils from Thymus vulgaris L., Rosmarinus officinalis L. and Origanum vulgare L. Food Chem., 74, 774-782.

13. Eliopoulos, G.M.; Moellering, R.C. (1997). Antimicrobial combinations. In: Lorian, V. (Ed.), Antibiotics in Laboratory Medicine. Williams and Wilkins, Baltimore, pp. 330-390.

14. Ettayebi, K.; Yamani, J.; Rossi-Hassani, B.D. (2000). Synergistic effects of nisin and thymol on antimicrobial activities in Listeria monocytogenes and Bacillus cereus. FEMS Microbiol. Lett., 183, 191-195.

15. Fu, Y.J.; Zu, Y.G.; Chen, L.Y.; Shi, X.G.; Wang, Z.; Sum, S.; Efferth, T. (2007). Antimicrobial activity of clove and rosemary essential alone and in combination. Phytother. Res., in press.

16. Gould, I.M.; Wilson, D.; Milne, K.; Peterson, A.; Golder, D.; Russel, D. (1991). Interaction of iminepen with erythromycin and tetracycline assessed by microdilution checkboard techniques. Antim. Agent. Chemother., 35, 2407-2409.

17. Gutierrez, J.; Barry-Ryan, C.; Bourke, P. (2008). The antimicrobial efficacy of plant essential oil combinations and interactions with food ingredients. Int. J. Food Microbiol., in press.

18. Jett, M.; Ionin, B.; Das, R.; Neill, R. (2001). The staphylococcal enterotoxins. In: Sussman M, editor. Molecular medical microbiology. San Diego, CA, USA: Academic Press; p. 1089-116.

19. Jørgensen, F.; Hansen, T.B.; Knochel, S. (1999). Heat shock-induced thermotolerance in Listeria monocytogenes 13-249 is dependent on growth phase, pH and lactic acid. Food Microbiol., 16, 185-194.

20. Jørgensen, H.J.; Mathisen, T.; Lovseth, A.; Omoe, K.; Qvale, K.S.; Loncarevic, S. (2005). An outbreak of staphylococcal food poisoning caused by enterotoxin $\mathrm{H}$ in mashed potato made with raw milk. FEMS Microbiol. Lett., 252, 267-272.

21. Juven, B.J.; Kanner, J.; Schved, F.; Weisslowicz, H. (1994). Factors that interact with the antimicrobial action of thyme essential oil and its active constituents. J. Appl. Bacteriol., 76, 623-631.

22. Karatzas, A.K.; Kets, E.P.W.; Smid, E.J.; Bennik, M.H.J. (2001).The combined action of carvacrol and high hydrostatic pressure on Listeria monocytogenes Scott A. J. Appl. Microbiol., 90, 463-469. 
23. Khreich, N.; Lamourette, P.; Boutal, H., Devilliers, K.; Crémininon, C.; Volland, H. (2008). Detection of Staphylococcus enterotoxin B using fluorescent immunoliposomes as label for immunochromatographic testing. Anal. Biochem., 377, 182-188.

24. Lambert, R.J.W.; Skandamis, P.N.; Coote, P.J.; Nychas, G.J.E. (2001). A study of minimum inhibitory concentration and mode of action of oregano essential, thymol and carvacrol. J. Appl. Microbiol., 91, 453-462.

25. Lin, Y.T.; Labbe, R.G.; Shetty, K. (2004). Inibition of Listeria monocytogenes in fish and meat system by use of oregano and cramberry phytochemical synergies. Appl. Environ. Microbiol., 70, $5672-5678$

26. Mackay, M.L.; Milne, K.; Gould, I.M. (2000). Comparison of methods for assessing synergic antibiotic interactions. Int. J. Antim. Agent., $15,125-129$.

27. Mendoza-Yepez, M.J.; Sanchez-Hidalgo, L.E.; Maertens, G.; MarinIniesta, F. (1997). Inhibition of Listeria monocytogenes and other bacteria by plant essential oil (DMS) on Spanish soft cheese. J. Food Saf., 17, 47-55.

28. Monk, J.D.; Beuchat, L.R.; Hathcox, A.K. (1996). Inhibitory effects of sucrose monolaurate, alone and in combination with organic acids, on Listeria monocytogenes and Staphylococcus aureus. J. Appl. Bacteriol., 81, 7-18.

29. Naveena, B.M.; Muthukumar, M.; Sen, A.R.; Babji, Y.; Murthy, T.R.K. (2006). Improvement of shelf-life of buffalo meat using lactic acid, cove oil and vitamin C during retail display. Meat Scie., 74, 409415.

30. Nazer, A.I.; Kobilinsky, A.; Tholozan, J.-L.; Dubois-Brissonnet, F. (2005). Combination of food antimicrobials at low levels to inhibit the growth of Salmonella sv, Typhimurium: a synergistic effect. Food Microbiol., 22, 391-39.

31. Nostro, A.; Blanco, A.R.; Canntelli, M.A.; Enea, V.; Flamini, G.; Morelli, I.; Roccaro, A.S.; Alonzo, V. (2004). Susceptibility of methicillin-resistant staphylococci to oregano essential oil, carvacrol and thymol. FEMS Microbiol. Lett., 230, 191-195.

32. Pandit, V.A.; Shelef, L.A. (1994). Sensitivity of Listeria monocytogenes to rosemary (Rosmarinus officinalis L.). Food Microbiol., 11, 57-63.
33. Patrignani, F.; Iucci, L.; Belletti, N.; Gardini, F.; Guerzoni, M.E.; Lanciotti, R. (2008). Effects of sub-lethal concentrations of hexanal and 2-(E)-hexenal on membrane fatty acid composition and volatile compounds of Listeria monocytogenes, Staphylococcus aureus, Salmonella enteritidis and Escherichia coli. Int. J. Food Microbiol., 123, 1-8.

34. Pol, L.E.; Mastwijk, H.C.; Slump, R.A.; Popa, M.E.; Smid, E.J. (2001). Influence of food matrix on inactivation of Bacillus cereus by combinations of nisin, pulsed electric fields treatment and carvacrol. J. Food Prot., 64, 1012-1018.

35. Seydim, A.C.; Sarikus, G. (2006). Antimicrobial activity of whey protein based edible films incorporated with oregano, rosemary and garlic essential oils. Food Res. Int., 39, 639-644.

36. Shetty, K.; Wahlqvist, M.L. (2004). A model for the role of prolinelinked pentose phosphate pathway in phenolic phytochemicals biosynthesis and mechanism of action from human health and environmental applications. Asia Pacific Journal of Clinical Nutrition, 13, 1-24.

37. Shriver-Lake, L.C., Shubin, Y.S.; Ligler, F.S. (2003). Detection of staphylococcal enterotoxin B in spiked food samples. J. Food Prot., 66, 1851-1856.

38. Skandamis, P.; Tsigarida, E.; Nichas, G.J.E. (2002). The effect of oregano essential oil on survival/death of Salmonella typhimurium in meat stored at $5^{\circ} \mathrm{C}$ under aerobic, VP/MAP conditions. Food Microbiol., 19, 97-108.

39. Souza, E.L.; Stamford, T.L.M.; Lima, E.O.; Trajano, V.N. (2007). Effectiveness of Origanum vulgare L. essential oil to inhibit the growth of food spoiling yeasts. Food Cont., 18, 409-413.

40. Ultee, A.; Smid, E.J. (2001). Influence of carvacrol on growth and toxin production by Bacillus cereus. J. Food Microbiol., 64, 373378.

41. Vanderzant, C.; Splittstoesser, D.F. (1992). Compendium of methods for the microbiological examination of foods. $3^{\mathrm{a}}$ ed. Washington American Public Health Association (APHA). 1219p.

42. Veras, J.F.; do Carmo, L.S.; Tong, L.C.; Shupp, J.W.; Cummings, C.; dos Santos, D.A.; Cerqueira, M.M.O.P.; Cantini, A.; Nicoli, J.R.; Jett, M. (2008). A study of the enterotoxigenicity of coagulasenegative and coagulase-positive staphylococcal. Int. J. Infect. Dis., in press. 